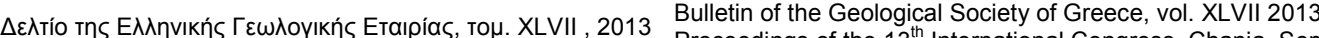
Proceedings of the $13^{\text {th }}$ International Congress, Chania Sept.

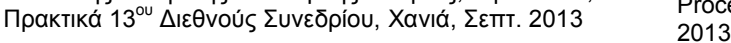

\title{
PRELIMINARY RESULTS OF HIGH RESOLUTION PALEOCEANOGRAPHY AND PALEOCLIMATOLOGY DURING SAPROPEL S1 DEPOSITION (SOUTH LIMNOS BASIN, NORTH AEGEAN SEA)
}

\author{
Kostopoulou S. ${ }^{1}$, Triantaphyllou M.B. ${ }^{1}$, Dimiza M.D. ${ }^{1}$, Gogou A. ${ }^{2}$, Boulou- \\ bassi I. ${ }^{3}$, Rousakis G. ${ }^{2}$, Parinos C. ${ }^{2}$, Diamantopoulou An. ${ }^{4}$, Geraga M. ${ }^{4}$ and \\ Lykousis $\mathbf{V}^{2}$ \\ ${ }^{I}$ Faculty of Geology and Geoenvironment, National and Kapodistrian University of Athens, \\ Panepistimiopolis 15784, Athens, kost.sofia@hotmail.com \\ ${ }^{2}$ Hellenic Centre for Marine Research, Institute of Oceanography, 19013 Anavyssos, Attiki \\ ${ }^{3}$ Laboratoire d'Océanographie et du Climat, Expérimentation et Approche Numérique, Université \\ Pierre et Marie Curie, Paris Cedex 05, France \\ ${ }^{4}$ Faculty of Geology, University of Patras, 26100 Rio-Patra
}

\begin{abstract}
The paleoenviromental conditions during the depositional interval of sapropel S1 in the northeastern Aegean (gravity core M-4, length $2.53 \mathrm{~m}$; south Limnos basin) are studied based on quantitative micropaleontological (benthic and planktonic foraminifera) and geochemical $\left(O C, \delta^{13} C_{o r g}\right)$ analyses. Special feature of core $M-4$ is the thickness of S1 layer $(96 \mathrm{~cm})$. Our study points that sapropelic layer Sla has been deposited in more dysoxic and warmer conditions in respect to S1b. Both primary productivity and preservation of organic material are more intense during the lower part of S1. An interruption of the sapropelic conditions at $8.0 \mathrm{Ka} \mathrm{BP}$ which is mainly characterized by the increase of agglutinated foraminiferal forms confirms both higher oxygen bottom conditions and freshwater input.

Key words: sapropel S1, foraminifera, geochemical indices, Aegean Sea.
\end{abstract}

\section{Пврі́ $\eta \psi \eta$}

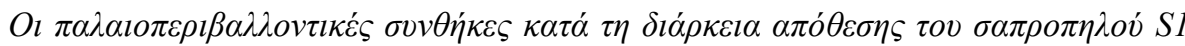

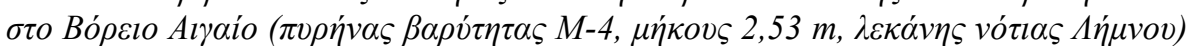

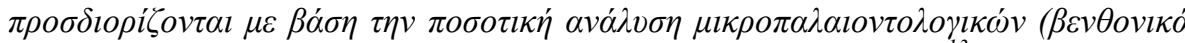

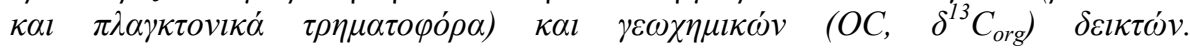

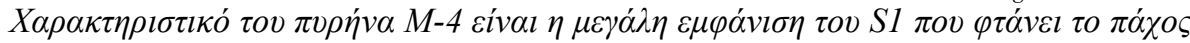

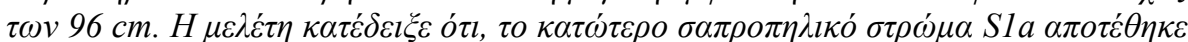

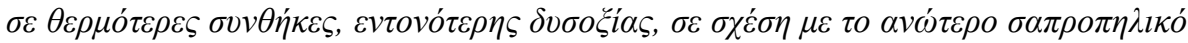

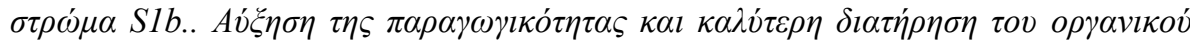

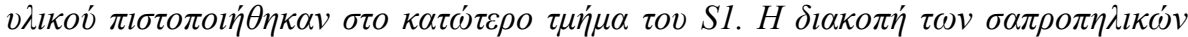

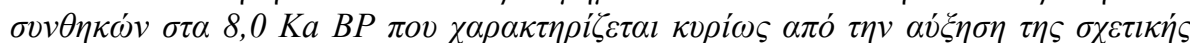

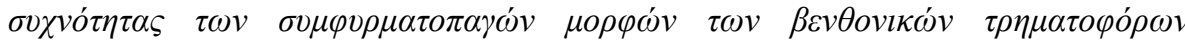

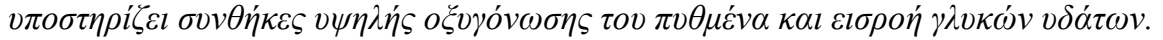

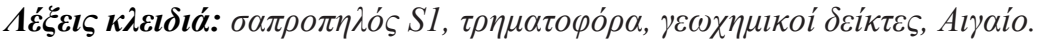




\section{Introduction}

The Aegean Sea is located at the northern part of NE Mediterranean region, linked to the Black Sea through the Dardanelles and the Bosporus Straits and to the eastern Mediterranean through the Cretan Straits, being recognized as a particularly important area for both regional and global climate changes. Numerous major rivers from the surrounding areas of the Balkans and Turkey flow into the Aegean Sea, providing the $75 \%$ of the North Aegean sediment influx (Lykousis et al., 2002; Roussakis et al., 2004; Ehrmann et al., 2007; Poulos, 2009), and they collectively constitute an important source of land-derived organic matter to the study area (e.g., Gogou et al., 2007). The Aegean receives low saline and cool BSW (Black Sea Water) through the Bosporus Strait (between Black Sea and Marmara Sea) and the Dardanelles (between Marmara Sea and Aegean Sea). The cold $\left(9-22^{\circ} \mathrm{C}\right)$ and low saline $(24-28 \%$ ) BSW flows along the eastern coast of Greece until it reaches the southwestern Aegean, and enhances the productivity in the northern Aegean Sea (Lykousis et al., 2002). The warm $\left(16-25^{\circ} \mathrm{C}\right.$ ) and saline (from 39.2 to $39.5 \%$ ) Levantine surface waters flow northward along the eastern Aegean Sea to the Dardanelles Straits (e.g., Zervakis et al., 2004). Especially for the basin of north Aegean Sea, it can be described as a «continental margin» ecosystem, and is characterized by generally cyclonic circulation (Lykousis et al., 2002).

The positive shift of the Aegean Sea's freshwater budget during sapropel deposition - possibly supplemented by enhanced freshwater inputs from the Southern European margin (Kotthoff et al., 2008) - weakened the basin's deepwater circulation and resulted in oxygen starved conditions at the seafloor. Recent paleoceanographic findings (e.g., Gogou et al., 2007; Triantaphyllou et al., 2009 a,b; Katsouras et al., 2010; Kouli et al., 2012) suggest that during the Holocene, a rather mild climatic period, between 10 and $6 \mathrm{kyr}$ BP, appeared in the sediments through the deposition of the most recent sapropel layer S1. Besides the monsoonal system, precipitation and inflow of Black Sea waters may have also contributed in modifying the freshwater budget during times of S1 formation (e.g., Kuhnt et al., 2007). A centennial-scale cold event centered on $8.2 \mathrm{ka}$ (Alley et al., 1997) coincides with the S1 interruption, and has been ascribed to a deepwater overturning reinforcement and reventilation.

In this study, we have performed micropaleontological (benthic and planktonic foraminifera) and geochemical (Organic Carbon; OC, $\delta^{13} \mathrm{C}_{\text {org }}$ ) analyses in sediments of core M-4 collected in the south Limnos basin, aiming to determine the paleoenvironmental changes during sapropel $\mathrm{S} 1$ deposition in north eastern Aegean Sea.

\section{Materials and Methods}

\subsection{Core Description}

Gravity core M-4 (length $2.53 \mathrm{~m}$ ) has been recovered in south Limnos basin (Figure 1a) from water depth $216 \mathrm{~m}$, at $39^{\circ} 38.662^{\prime} \mathrm{N} 25^{\circ} 35.165^{\prime} \mathrm{E}$. Sapropel S1 is very well exposed in between $128-32 \mathrm{~cm}$, with overall thickness reaching $96 \mathrm{~cm}$. The uppermost $32 \mathrm{~cm}$ mainly consist of gray mud with shells (e.g., Ostrea) and shell debris. Based on sediment color and the concentration of $\mathrm{OM}$, the $\mathrm{S} 1$ layer is divided into two sub-units (hereafter termed S1a and S1b, respectively), which are separated by an $8 \mathrm{~cm}$ thick (from 58 to $51 \mathrm{~cm}$ ) lighter gray interval interpreted as the S1 interruption (Figure 1b). In this paper only the interval relative to sapropel S1 will be examined.

\subsection{Chronology}

Three accelerator mass spectrometry (AMS) radiocarbon ${ }^{14} \mathrm{C}$ datings were performed at the laboratories of the oceanographic institute LOCEAN/Universite P.-M. Curie, on cleaned hand-picked planktonic foraminifera from core $\mathrm{M}-4$. Conventional ${ }^{14} \mathrm{C}$ ages have been calibrated by using Calib vs. 6.1.0 software (Stuiver et al., 1993) and the MARINE04 calibration dataset with a regional reservoir age correction $(\Delta \mathrm{R})$ of $139 \pm 40$ (Facorellis et al., 1998). The age model of the core M-4 
resulted from the linear interpolation between three calibrated datings. According to this model, $\mathrm{S} 1 \mathrm{a}$ is deposited between 9.7-8.0 ka BP, whereas S1b spans 7.6-6.5 Ka BP. The age resolution between the samples is 38-163 years for S1b, 38-39 years for the interruption and 24-73 years for S1a.

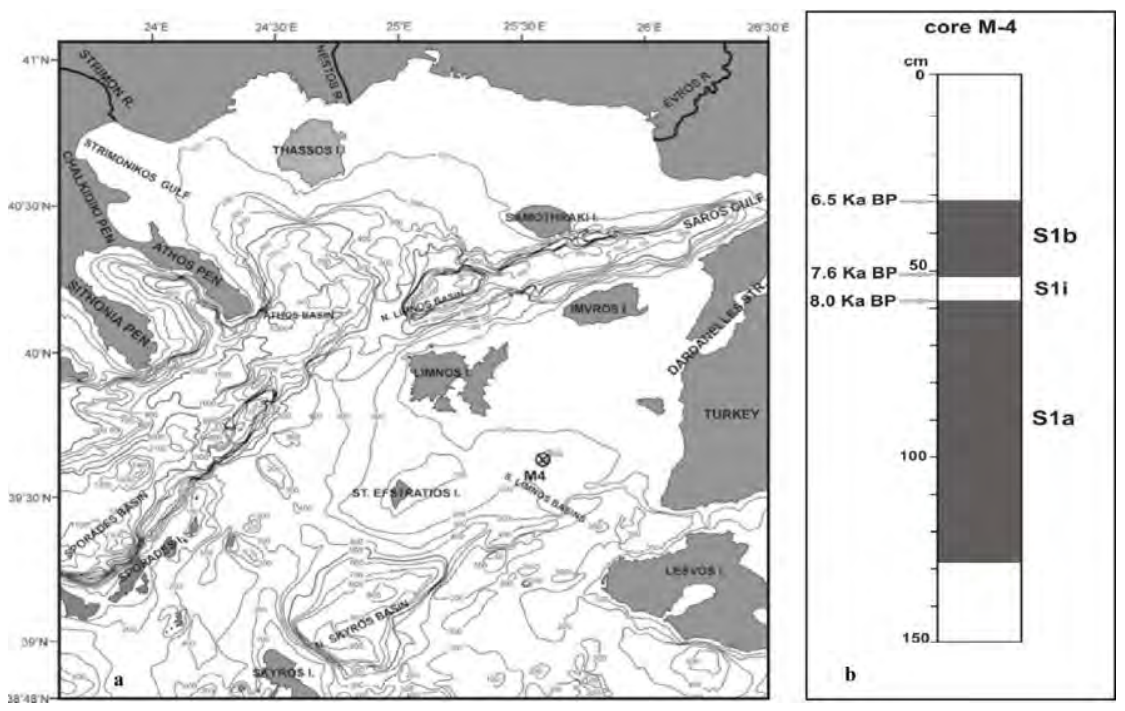

Figure 1 - (a) Location map of the study area in the north-eastern Aegean Sea, (b) Gravity core M-4 (the upper $150 \mathrm{~cm})$.

\section{Methods}

Two hundred and thirty samples were collected at $0.5 \mathrm{~cm}$ resolution for organic carbon (OC) content, $\delta^{13} \mathrm{C}_{\text {org. }}$. Analyses were performed using an automatic analyzer type "NA-1500 Nitrogen Analyzer". Stable carbon isotope ratios were expressed in terms of $\delta^{13} C_{\text {org }}$ values against V-PDB for carbon, with overall analytical error based on duplicate measurements at $\pm 0.2 \%$.

For benthic foraminiferal analyses, sixty four sediment samples of approximately $2 \mathrm{~g}$ dry weight each were wet sieved over $63 \mu \mathrm{m}$ sieve at resolution $0.5-3 \mathrm{~cm}$. For each sample, a subset containing at least 300 benthic foraminifera were separated from the $>125 \mu \mathrm{m}$ fraction using a Leica APO S8 stereoscope. A scanning electron microscope analysis (SEM Jeol JSM 6360, Dept. of Hist. Geology-Paleontology) has been used for taxonomical purposes. Relative abundances of benthic foraminifera are presented and discussed in this study. Benthic foraminifera have been used as tracers for the nutrient content and oxygen concentration of the bottom water (e.g., Jorissen et al., 1995).

Forty six samples were used for planktonic foraminifera analysis. The mean sampling interval for the faunal analyses was $2 \mathrm{~cm}$. The samples were disintegrated by hydrogen peroxide and then sieved through a $125-\mu \mathrm{m}$ mesh. The dry and weighed samples were split into separate aliquots. At least 200 planktonic specimens were identified and counted in each sample. Planktonic foraminifera have been proven useful in the reconstruction of palaeoceanographic and palaeoclimatic conditions (Bé \&Tolderlund, 1971; Pujol \& Vergnaud Grazzini, 1995). The sum of the percentages of species considered as indicative of warm waters versus the sum of those indicative of cool waters obtained as an index for the examination of the of the sea surface palaeotemperature and will be referred as PSST (Planktonic Sea Surface Temperature). Globigerinoides ruber, Globigerinoides sacculifer, Orbulina univera and Globigerinella spp. are considered warm-water indicators and Turborotalita quinqueloba, Globigerinita glutinata and Globorotalia scitula cold-water indicators (Thunell, 1978; Pujol \& Vergnaud Grazzini, 1995). 


\section{Results}

\subsection{OC and $\delta^{13} \mathrm{C}_{\text {org }}$}

Higher OC values correspond to sapropel layers S1a and S1b (Figure 2). The maximum value of $1.94 \%$ is observed at $8.9 \mathrm{Ka} \mathrm{BP}$ during the deposition of S1a, whereas $1.67 \%$ is identified at 7.1 $\mathrm{Ka} \mathrm{BP}$. The interval of 8.0-7.6 Ka BP (S1 interruption) is characterized by a reduction of OC, however an increase to $1.26 \%$ exists at $7.7 \mathrm{Ka} \mathrm{BP}$, just before the onset of $\mathrm{S} 1 \mathrm{~b} . \delta^{13} \mathrm{C}_{\text {org }}$ values of range from $-26.1 \%$ to $-22.9 \%$ (Figure 2). The minimum values of $\delta^{13} \mathrm{C}_{\text {org }}$ were found during the interruption of sapropel S1 (7.7 Ka BP).

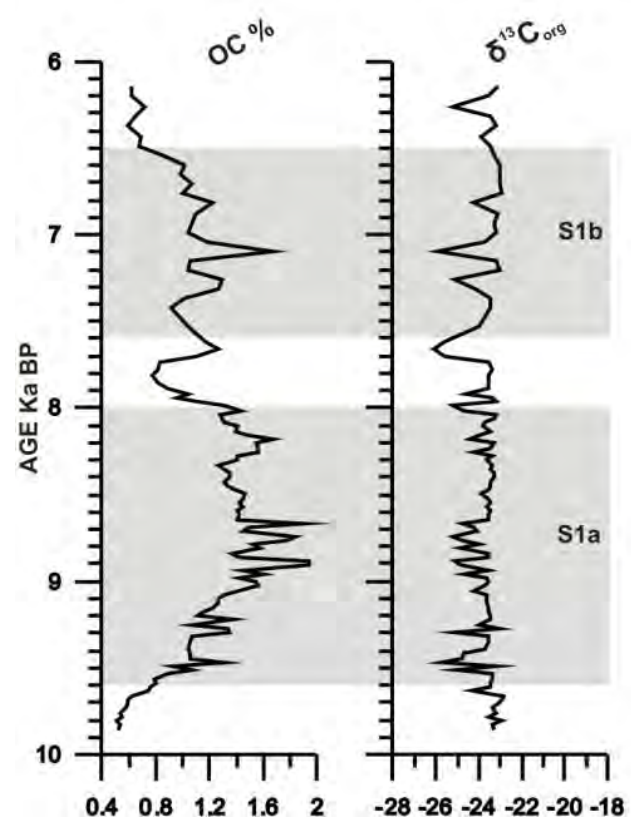

Figure 2 - Percentage concentration of organic carbon and vertical distribution of $\delta^{13} C_{\text {org }}$ values of gravity core $\mathrm{M}-4$.

\subsection{Benthic Foraminifera}

The presence of benthic foraminifera is continuous throughout the core M-4 (Figure 3). Chilostomella mediterranensis is found in S1 lobes reaching almost $30 \%$ at $8.6 \mathrm{Ka}$ BP during S1a and $25.4 \%$ at $6.8 \mathrm{Ka} \mathrm{BP}$. Bolivina striatula peaks at $8.1 \mathrm{Ka} \mathrm{BP}(12.9 \%)$, decreases during the interruption of S1, but culminates again during the deposition of S1b. Bolivina spathulata displays low values during S1a; the highest abundance $(29.9 \%)$ is observed at $7.8 \mathrm{Ka} \mathrm{BP}$, followed by a gradual reduction during S1b. Brizalina alata is strongly fluctuating during S1 deposition, with abundances more pronounced within S1a. Bulimina spp. represents a significant component of sapropel microfauna, with an increasing trend in between $9-8.3 \mathrm{ka}$ BP. The species Globobulimina affinis dominates the benthic assemblages of S1a, reaching $71.8 \%$ at $9 \mathrm{Ka} \mathrm{BP}$. After $8 \mathrm{Ka} \mathrm{BP}$, it is practically absent, with sporadic appearances, not exceeding $1-2 \%$. Cassidulinoides bradyi is featured by a similar pattern, but with much lower abundance (max. $4.9 \%$ at $9.2 \mathrm{Ka} \mathrm{BP}$ ). Uvigerina mediterranea reaches up to $24.2 \%$ at the beginning of layer S1a $(9.6 \mathrm{Ka} \mathrm{BP})$. Upwards it presents a gradual decrease, with another peak of $16.9 \%$ at the top of S1a $(7.9 \mathrm{Ka} \mathrm{BP})$; values are also increasing during S1b but to lesser degree. Hyalinea balthica increases significantly within S1b, showing a maximum of $16.7 \%$, at $7 \mathrm{Ka}$ BP whereas Melonis barleeanum, agglutinants and miliolids occur in very low rates inside S1, but increase significantly outside the sapropel depositional interval. 


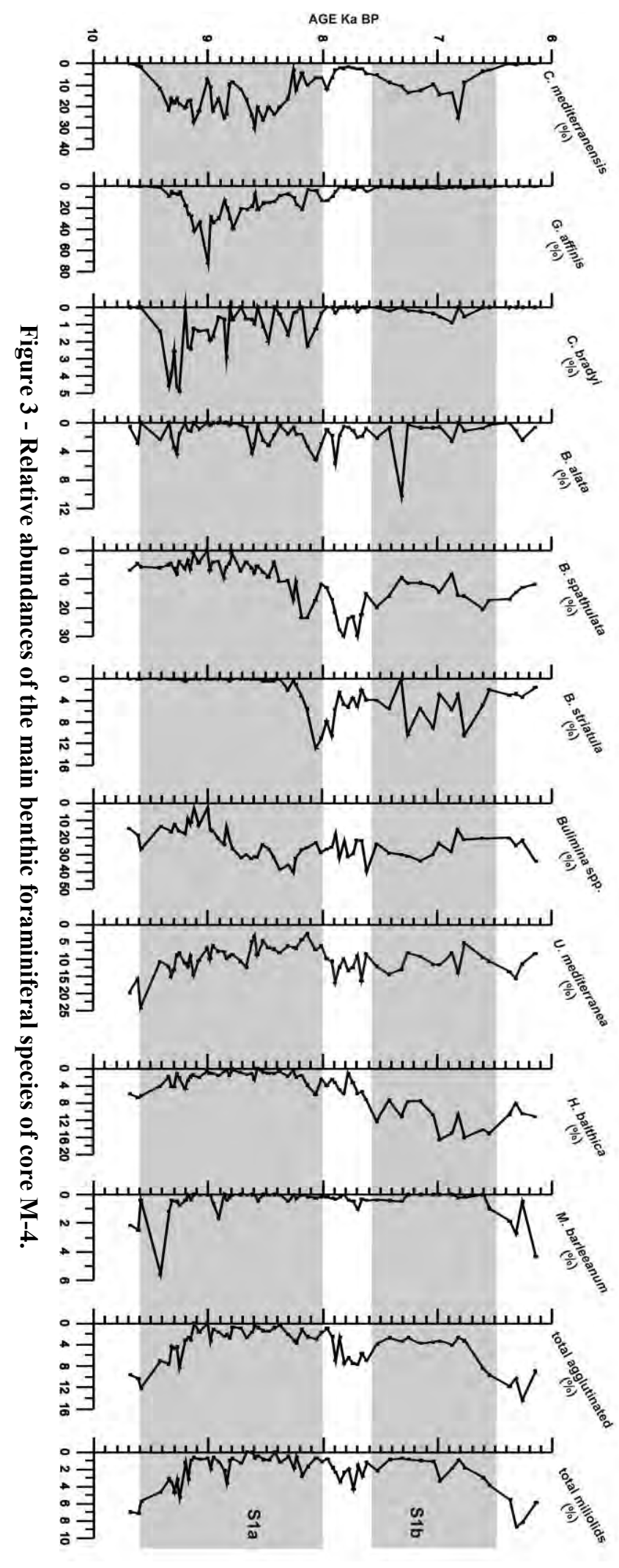

XLVII. No 1 - 198 


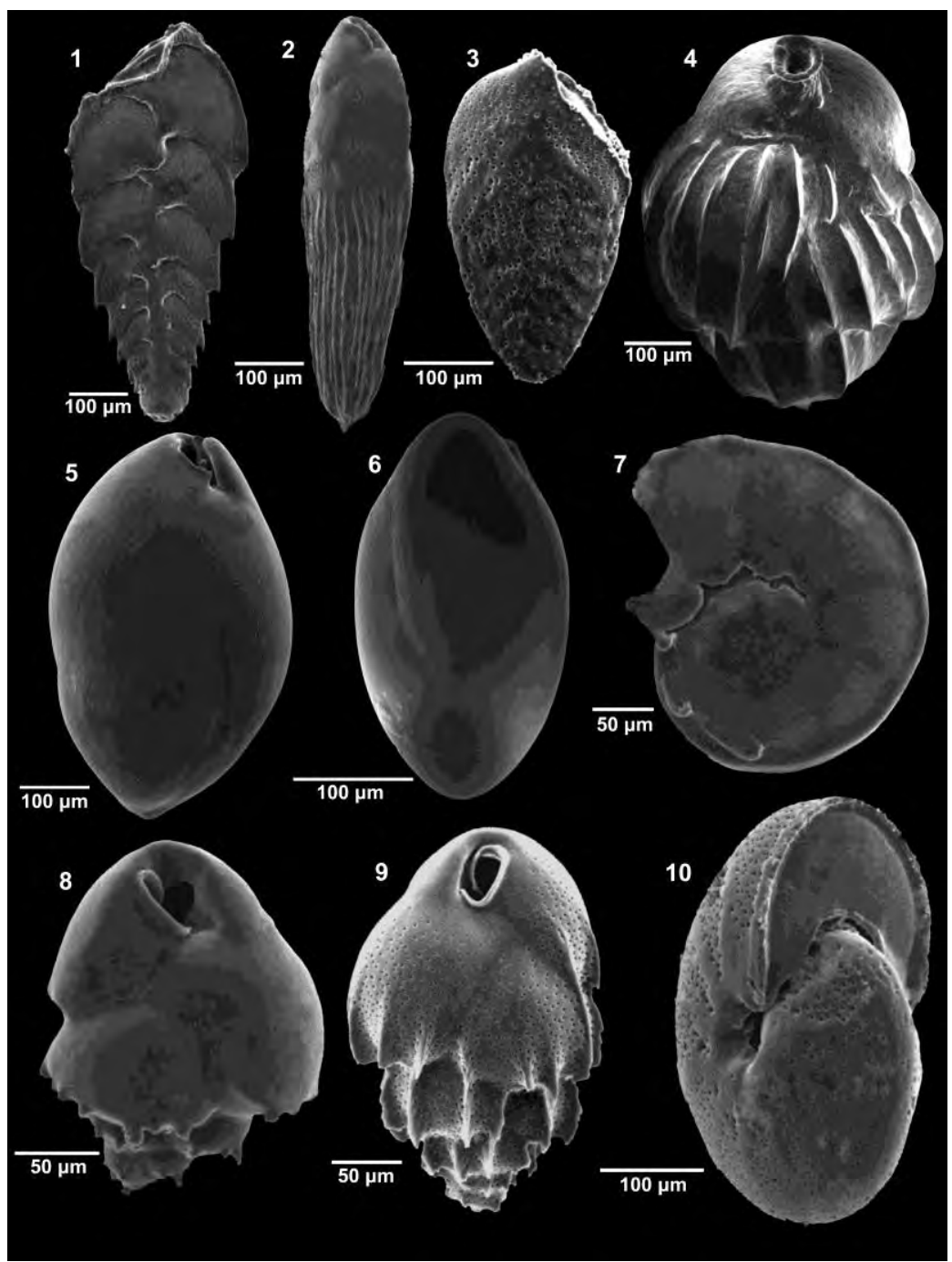

Plate I - 1. Bolivina alata (Seguenza), M-4, 88-88.5 cm 2. Brizalina striatula (Cushman), M-4, 38-38.5 cm 3. Bolivina spathulata (Williamson), M-4, 38-38.5 cm 4. Uvigerina mediterranea (Hofker), M-4, 33-33.5 cm 5. Globobulimina affinis (d'Orbigny), M-4, 63$63.5 \mathrm{~cm}$ 6. Chilostomella mediterranensis (Cushman \& Todd), $M-4,90-90.5 \mathrm{~cm} 7$. Hyalinea balthica (Schröeter), M-4, 63-63.5 cm 8. Bulimina marginata (d'Orbigny), M-4, $38-38.5 \mathrm{~cm}$ 9. Bulimina costata (d'Orbigny), M-4, 88-88.5 cm 10. Melonis barleeanum (Williamson), M-4, 110-110.5 cm.

\subsection{Planktonic Foraminifera}

Along the core sediments planktonic foramifera assemblages are abundant and consist mainly of Gs. ruber (0-30\%), Gs. sacculifer (0-13\%), Or. universa (0-7\%), Globigerina bulloides (5-45\%), T. quinqueloba (5-75\%), G. glutinata (0-5\%), Neogloboquadrina spp. (0-13\%) and Globorotalia inflata $(0-12 \%)$. Similar is also the modern foraminiferal assemblages in the studied area (Thunell, 1978). The downcore variations of the PSST index presents an increasing trend upwards (Figure 4). The eutrophicated species have always high participation in the planktonic assemblages ranging about 60 to $90 \%$ of the total association, suggesting high eutrophicated levels throughout the deposition of S1. However the largest percentages occur during the deposition of S1a. 


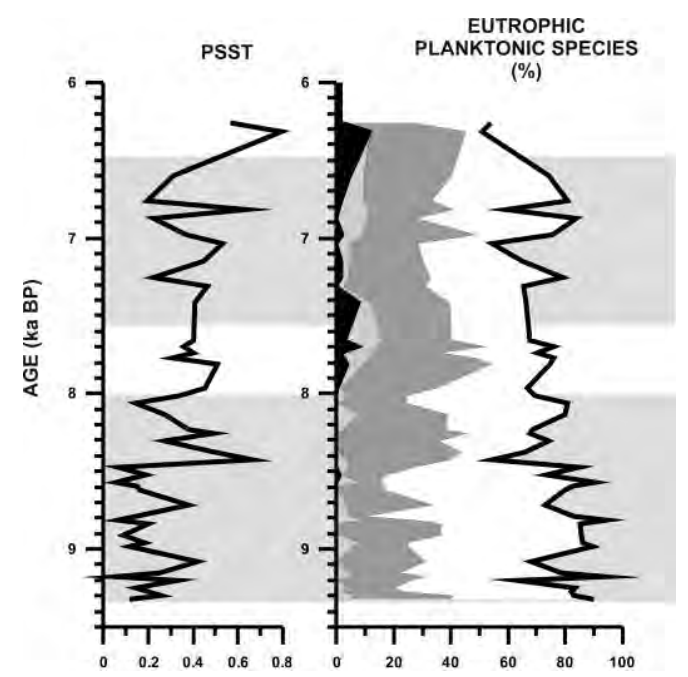

Figure 4 - a. Downcore variation of the Planktonic Sea Surface Temperature (PSST) curve, b. Relative abundances of the eutrophic planktonic foraminifera species of core M-4 (colours: black: Gr. inflata; light gray: Neogloboquadrinds; dark gray: G. bulloides; white: $T$. quinqueloba).

\section{Discussion and Conclusions}

Sapropel S1a interval in south Limnos basin is characterized by the intense presence of anoxic/dysoxic benthic species (Figure 3), such as C. mediterranensis, G. affinis and C. bradyi (e.g., Bernard \& Sen Gupta, 1999; Fontanier et al., 2002; Kuhnt et al., 2007; Abu-Zied et al., 2008). In addition, Bulimina spp. (B. aculeata, B. marginata and B. costata), which are indices of extreme eutrophic and dysoxic conditions (e.g., Bernhard \& Alve, 1996), along with the presence of $B$. spathulata, $B$. striatula and $B$. alata which are also living in low oxygen environments, and are relatively tolerant to non-oxic conditions (e.g., Jorissen et al., 1995) support dysoxic conditions within sapropelic layer S1a. However, S1a depositional interval is also featured by the presence of $U$. mediterranea, which has low tolerance to dysoxic conditions and prefers mesotrophic to eutrophic environments (e.g., Jorissen et al., 1995; Schmiedl et al., 2000). H. balthica, although in low abundances, indicates well oxygenated waters (e.g., Aksu et al., 1995; Morigi et al., 2001; AbuZied et al., 2008), while Gyroidinoides spp. also support higher oxygen conditions (e.g., Edelmann-Furstenberg et al., 2001). Therefore, there is ample evidence that less severe dysoxia has been developed in south Limnos basin during the deposition of layer S1a, in respect to what has been documented before for other Aegean basins (e.g., Kuhnt et al., 2007; Abu-Zied et al., 2008; Triantaphyllou et al., 2009a, b; Geraga et al., 2005, 2010).

Higher values of OC during the deposition of S1a than those of S1b indicate highest organic matter production and preservation in S1a, supporting previous results in the Aegean area (e.g., Gogou et al., 2007; Triantaphyllou et al., 2009b; Katsouras et al., 2010). The almost constant values of $\delta^{13} \mathrm{C}_{\text {org }}$ during S1a, confirm the hypothesis that the deposition of sapropel S1 depends on primary productivity and preservation of organic matter (Katsouras et al., 2010). During the depositions of $\mathrm{S} 1 \mathrm{a}$ and S1b the dominant planktonic species are T. quinqueloba and G. bulloides (Figure 4). $T$. quinqueloba is indicative of cool waters, but is also tolerant to fairly low salinity and/or enhanced fertility in surficial waters (Rohling et al., 1997). High percentages of this taxon have been reported in the sediments of S1 in Aegean Sea. However, this pattern seems to be stronger in N. Aegean basins (Geraga et al., 2010) rather than in S. Aegean basins (e.g., Geraga et al., 2000; Triantaphyllou et al., 2009a). G. bulloides is indicative of sub-polar water masses highly dependent on enhanced food levels (upwelling, strong seasonal mixing or freshwater inputs, Lourens et al., 1994). The abundant presence of $G$. bulloides and T. quinqueloba suggests the development of a 
low salinity surficial layer rich in nutrients over south Limnos basin during the deposition of S1a and S1b.

The interruption of sapropel S1 at $8.0 \mathrm{Ka}$ BP can be associated with the north hemisphere cold event at $8.2 \mathrm{Ka}$ BP. During the sapropel interruption interval, the increase of agglutinated forms confirms both higher oxygen bottom conditions and freshwater input (e.g., Alve, 1995). This is accompanied by decrease in $\mathrm{OC}$ and the presence of planktonic foraminifera assemblages which suggest stronger mixing of the water column at least during winter. The more negative values of $\delta^{13} \mathrm{C}_{\text {org }}$ identified at $7.7 \mathrm{Ka} \mathrm{BP}(-26.1 \%$ ) are indicative of terrigenous organic matter (e.g., Meyers $\&$ Arnaboldi, 2008; Katsouras et al., 2010) that may caused high value (1.26\%) of OC, during the interruption interval.

Within the sapropelic layer $\mathrm{S} 1 \mathrm{~b}$ dysoxic foraminiferal species abundances are once more increased but to a lesser degree when comparing with S1a; in accordance with OC values and the relatively lower participation of the eutrophic planktonic assemblages. U. mediterranea, H. balthica, miliolids and agglutinants are increased, supporting even less dysoxia for S1b interval in respect to S1a, in south Limnos basin. Furthermore, the gradual increase of $H$. balthica, an indicator of cold environments (e.g., Aksu et al., 1995), during S1b confirms that this interval is featured by lower temperature conditions (e.g., Gogou et al., 2007; Triantaphyllou et al., 2009b). This fact is also supported by the increase of $U$. mediterranea (Figure 4), a species that occurs at the final stage or subsequently after cold events (Kuhnt et al., 2007).

Minimum values of the PSST have been obtained during the S1a deposition. Low PSST values are also recorded during the deposition of S1b. Both these intervals are associated with the high abundance of T. quinqueloba. This taxon is indicative of high fertility and cool waters but is also tolerant to fairly low salinity (Rohling et al., 1997). Therefore the low PSST values may have been partly misled from the prevalence of low salinity surface waters occurred in that time. However the establishment of cool surface waters during the deposition of S1 is in agreement with other relative studies (i.e. Aksu et al., 1995). Low PSST values occur also at the late stages of S1a in accordance to the prevalence of the cold event at $8.2 \mathrm{Ka}$ (Alley et al., 1997).

An increase in the abundances of Gr. inflata and Neogloboquadrinds is obtained during the interruption of S1 and the late stages of the deposition of S1b. Gr. inflata is associated with cool and deep mixed waters (Thunell, 1978; Pujol \& Vergnaud Grazzini, 1995; Casford et al., 2002) and Neogloboquadrinids of eutrophicated waters associated with the formation of a Deep Chlorophyll Maximum (DCM) layer (Fairbanks \& Wiebe, 1980). Therefore their strong presence in these two intervals indicates less stratified waters in relation to those prevailed during the deposition of S1a and S1b.

All acquired data records present rapid simultaneous fluctuations, suggesting short term paleoceanographic and palaeoclimatic changes in the studied area. Rapid palaeoclimatic changes during the discussed interval have been also reported in pollen records from N. Aegean Sea (Kotthoff et al., 2008).

\section{Acknowledgments}

This work has been made possible thanks to the financial support provided by the European Research Project MarinERA/ MedEcos and Research Project KA 70/4/11078 of the University of Athens. Thoughtful discussions with T. Kuhnt are greatly appreciated. Thanks are due to two anonymous reviewers for providing constructive comments on the manuscript.

\section{References}

Abu-Zied R.H., Rohling E., Jorissen F.J., Fontanie C., Casford, J.S.L. and Cooke S. 2008. Benthic foraminiferal response to changes in bottom-water oxygenation and organic carbon flux in the eastern Mediterranean during LGM to Recent times, Mar. Micropal., 67, 46-68. 
Aksu A.E., Yasar D., Mudie P.J. and Gillespie H. 1995. Late glacial-Holocene paleoclimatic and paleoceanographic evolution of the Aegean Sea: micropaleontological and stable isotopic evidence, Mar. Micropal., 25, 1-28.

Alley R.B., Mayewski P.A., Sowers T., Stuiver M., Taylor K.C. and Clark P.U. 1997. Holocene c limatic instability: a prominent, widespread event 8200 yr ago, Geology, 25, 483- 486.

Alve E. 1995. Benthic foraminifera response to estuarine pollution: a review, J. Foraminiferal Res., 25, 190-203.

Bé A.W.H. and Tolderlund D.S., 1971, Distribution and ecology of living planktonic foraminifera in surface waters of the Atlantic and Indian Oceans, In: Funnell, B.M., Riedel, W.R., (Eds), The Micropalaeontology of Oceans, Cambridge University Press, 105-149

Bernhard J.M. and Alve E. 1996. Survival, ATP pool, and ultrastructural characterization of benthic foraminifera from Drammensfjord (Norway): response to anoxia, Mar. Micropal., 28, $5-17$.

Bernard J.M. and Sen Gupta B.K. 1999. Foraminifera of oxygen-depleted environments, In: Sen Gupta, B.K. (Ed.), Modern Foraminifera, Kluwer Academic Publishers, 201-216.

Edelmann-Furstenberg Y., Scherbacher M., Hemleben C. and Almogi- Labin A. 2001. Deep-sea benthic foraminifera from the central Red Sea, J. Foraminiferal Res., 31, 48-9.

Casford J.S.L., Rohling E.J., Abu-Zied R., Cooke S., Fontanier C., Leng M. and Lykousis V., 2002. Circulation changes and nutrient concentrations in the late Quaternary Aegean Sea: a nonsteady state concept for sapropel formation, Paleoceanography, 17, 1024-1034.

Ehrmann W., Schmiedl G., Hamann Y., Kuhnt T., Hemleben C. and Siebel W. 2007. Clay minerals in late glacial and Holocene sediments of the northern and southern Aegean Sea, Palaeogeogr. Palaeoclimatol. Palaeoecol., 249, 36-57.

Facorellis Y., Maniatis Y. and Kromer B. 1998. Apparent 14C ages of marine mollusk shells from a Greek island: calculation of the marine reservoir effect in the Aegean Sea, Radiocarbon, 40, 963-973.

Fairbanks R.G. and Wiebe P.H., 1980. Foraminifera and Chlorophyll Maximum: vertical distribution, seasonal succession, and paleoceanographic significance, Science, 209, 1524-1526.

Fontanier C., Jorissen F.J., Licari L., Alexandre P., Anschutz P. and Carbonel P. 2002. Live benthic foraminiferal faunas from the Bay of Biscay: faunal density, composition, and microhabitats, Deep-Sea Res. Oceanogr., A, 49, 751-785.

Geraga M., Tsaila-Monopolis S., Ioakim C., Papatheodorou G. and Ferentinos G. 2000. Evaluation of palaeoenvironmental changes during the last 18,000 years in the Myrtoon basin, SW Aegean Sea, Palaeogeogr. Palaeoclimatol. Palaeoecol., 156, 1-17.

Geraga M., Tsaila-Monopolis S., Ioakim C., Papatheodorou G. and Ferentinos G. 2005. Short-term climate changes in the southern Aegean Sea over the last 48,000 years, Palaeogeogr. Palaeoclimatol. Palaeoecol., 220, 311-332.

Geraga M., Ioakim C., Lykousis V., Tsaila-Monopolis S. and Mylona G. 2010. The high resolution palaeoclimatic and palaeoceanographic history of the last 24,000 years in the central Aegean Sea, Greece, Palaeogeogr. Palaeoclimatol. Palaeoecol., 287, 101-115.

Gogou A., Bouloubassi I., Lykousis V., Arnaboldi M., Gaitani P. and Meyers P.A. 2007. Organic geochemical evidence of abrupt late glacial-Holocene climate changes in the North Aegean Sea, Palaeogeogr. Palaeoclimatol. Palaeoecol., 256, 1-20.

Jorissen F.J., De Stigter H.C. and Widmark J.G.V. 1995. A conceptual model explaining benthic foraminiferal microhabitats, Mar. Micropal., 26, 3-15.

Katsouras G., Gogou A., Bouloubassi I., Emeis K.C., Triantaphyllou M., Roussakis G. and Lykousis V. 2010. Organic carbon distribution and isotopic composition in three records from the eastern Mediterranean Sea during the Holocene, Org. Geochem., 41, 935-939.

Kotthoff U., Pross J., Muller U.C., Peyron O., Schmiedl G., Schulz H. and Bordon A. 2008. Climate dynamics in the borderlands of the Aegean Sea during formation of sapropel S1 deduced from a marine pollen record, Quat. Sci. Rev., 27, 832-845.

Kouli K., Gogou A., Bouloubassi I., Triantaphyllou M.V., Ioakim Chr., Katsouras G., Roussakis G. and Lykousis V. 2012. Late postglacial paleoenvironmental change in the 129 northeast- 
ern Mediterranean region: Combined palynological and molecular biomarker evidence, Quat. Int., 261, 118-127.

Kuhnt T., Schmiedl G., Ehrmann W., Hamann Y. and Hemleben C. 2007. Deep-sea ecosystem variability of the Aegean Sea during the past $22 \mathrm{kyr}$ as revealed by Benthic Foraminifera, Mar. Micropal., 64, 141-162.

Lourens L.J., Hilgen F.J., Gudjonsson L. and Zachariasse W.J. 1994. Late Pliocene to Early Pleistocene astronomically forced sea surface productivity and temperature variations in the Mediterranean, in: Lourens, L.J., (Ed.), Astronomical Forcing of Mediterranean Climate During the Last 5.3 Million Years, Universiteit Utrecht, 37-58.

Lykousis V., Chronis G., Tselepides A., Price N.B., Theocharis A., Siokou-Fragou I., van Wambeke F., Danovaro R., Stavrakakis S., Duineveld G., Georgopoulos D., Ignatiades L., Souvermezoglou A. and Voutsinou-Taliadouri F. 2002. Major outputs of the recent multidisciplinary biogeochemical researches undertaken in the Aegean Sea, J. Mar. Syst., 33-34, 313-334.

Meyers P.A. and Arnaboldi M. 2008. Paleoceanographic implications of nitrogen and organic carbon isotopic excursions in mid-Pleistocene sapropels from the Tyrrhenian and Levantine Basins, Mediterranean Sea, Palaeogeogr. Palaeoclimatol. Palaeoecol., 266, 112-118.

Morigi C., Jorissen F.J., Gervais A., Guichard S. and Borsetti A.M. 2001. Benthic foraminiferal faunas in surface sediments off NW Africa: Relationship with the organic flux to the ocean floor, J. Foraminiferal Res., 31, 350-361.

Poulos S.E. 2009. Origin and distribution of the terrigenous component of the unconsolidated surface sediment of the Aegean floor: A synthesis, Cont. Shelf Res., 29, 2045-2060.

Pujol C. and Vergnaud Grazzini C. 1995. Distribution patterns of live planktic foraminifers as related to regional hydrography and productive systems of the Mediterranean Sea, Mar. Micropal., 25, 187-217.

Rohling E.J., Jorissen F.J. and De Stigter H.C. 1997. 200 year interruption of Holocene sapropel formation in the Adriatic Sea, J. Micropaleontol., 16, 97-108.

Roussakis G., Karageorgis A.P., Conispoliatis N. and Lykousis V. 2004. Last glacial-Holocene sediment sequences in N. Aegean basins: structure, accumulation rates and clay mineral distribution, Geo-Mar. Lett., 24, 97-111.

Schmiedl G., de Bovée F., Buscail R., Charrière B., Hemleben C., Medernach L. and Picon P. 2000. Trophic control of benthic foraminiferal abundance and microhabitat in the bathyal Gulf of Lions, western Mediterranean Sea, Mar. Micropal., 40, 167-188.

Stuiver M. and Reimer P.J. 1993. Extended C-14 data-base and revised Calib 3.0 C-14 age calibration program, Radiocarbon, 35, 215-230.

Thunell R.C. 1978. Distribution of recent planktonic foraminifera in surface sediments of the Mediterranean Sea, Mar. Micropal., 3, 147-173.

Triantaphyllou M.V., Antonarakou A., Kouli K., Dimiza M., Kontakiotis G., Papanikolaou M., Ziveri P., Mortyn G., Lianou V., Lykousis V. and Dermitzakis M.D. 2009a. Comparing Late Glacial - Holocene Plankton ecozones and Pollen Assemblage Zones: Basis for a multi-proxy ecostratigraphy in the south-eastern Aegean Sea (E. Mediterranean), Geo-Mar. Lett., 29, 249-267.

Triantaphyllou M.V., Ziveri P., Gogou A., Marino G., Lykousis V., Bouloubassi I., Emeis K.C., Kouli K., Dimiza M., Rosell-Mele A., Papanikolaou M., Katsouras G. and Nunez N. 2009 b. Late Glacial-Holocene climate variability at the south-eastern margin of the Aegean Sea, Mar. Geology, 266, 182-197.

Zervakis V., Georgopoulos D., Karageorgis A.P. and Theocharis A. 2004. On the response of the Aegean Sea to climatic variability: a review, Int. J. Climatol., 24, 1845-1858. 